\title{
Fiberglass Plaster Mesh as Reinforcement for Cement Bonded Partialeboard
}

\section{Učinci ojačanja cementom vezane iverice primjenom fasadne mrežice od stakloplastike}

\author{
Original scientific paper • Izvorni znanstveni rad \\ Received-prispjelo: 23. 6. 2020. \\ Accepted-prihvaćeno: 14. 1. 2021. \\ UDK: $630 * 863.21$ \\ https://doi.org/10.5552/drvind.2021.2027
}

\begin{abstract}
The effects of fiberglass plaster mesh (FPM) as reinforcement on some physical and mechanical properties of cement bonded particleboard (CBP) were examined. Experimental CBP with and without FPM were manufactured in laboratory conditions using wood particles, cement, tap water and chemical accelerators. Two plies of FPM, manufactured using fiberglass and polyester resin, were laid within the experimental CBP. The target density of $C B P$ was $1300 \mathrm{~kg} / \mathrm{m}^{3}$ in the study. Three different types of chemical accelerators (CaCl, $\mathrm{KCl}, \mathrm{DARA}$ SET® 580) were used in the experiments. Properties of CBP evaluated include 2- and 24-hour - thickness swelling (TS), 2- and 24-hour - water absorption (WA) and bending stiffness (MOE) and strength (MOR). The results indicate that all the board properties tested were significantly improved by FPM application. The average MOE values of the CBP boards with FPM was two times higher than those of the boards without FPM. Dimensional stability and MOR of the CBP boards were also significantly improved with the use of FPM. FPM can be used to improve inferior properties of the CBP, so as to make it more compatible with other wood based construction materials.
\end{abstract}

Keywords: cement bonded particleboard; fiberglass plaster mesh; physical and mechanical properties

SAŽETAK • U radu su ispitani učinci fasadne mrežice od stakloplastike kao ojačanja cementom vezanih iverica na neka njihova fizička i mehanička svojstva. Eksperimentalne cementom vezane iverice proizvedene su s fasadnom mrežicom od stakloplastike i bez nje u laboratorijskim uvjetima, i to upotrebom drvnog iverja, cementa, vode iz slavine i kemijskih ubrzivača. Dva sloja fasadne mrežice od stakloplastike, izrađene od staklenih vlakana i poliesterske smole, položena su u eksperimentalnu cementom vezanu ivericu. U istraživanju je ciljana gustoća cementom vezane iverice bila $1300 \mathrm{~kg} / \mathrm{m}^{3}$. U pokusima su upotrijebljene tri različite vrste kemijskih ubrzivača ( $\mathrm{CaCl}_{2}, \mathrm{KCl}, \mathrm{DARASET}{ }^{\circledR}$ 580). Proučavana su ova svojstva cementom vezane iverice: debljinsko bubrenje nakon 2 i 24 sata, upijanje vode nakon 2 i 24 sata, modul elastičnosti i modul loma. Rezultati pokazuju da su upotrebom fasadne mrežice od stakloplastike sva proučavana svojstva znatno poboljšana. Prosječne vrijednosti modula elastičnosti cementom vezane iverice s dodatkom fasadne mrežice od stakloplastike bile su dva puta veće od vrijednosti iverice bez dodatka takve mrežice. Dimenzijska stabilnost i modul loma cementom vezane iverice također su znatno poboljšani primjenom fasadne mrežice od stakloplastike. Fasadna mrežica od stakloplastike može se rabiti za poboljšanje lošijih svojstava cementom vezane iverice kako bi ona bila kompatibilnija s drugim građevnim materijalima na bazi drva.

Ključne riječi: cementom vezana iverica; fasadna mrežica od stakloplastike; fizička i mehanička svojstva

\footnotetext{
${ }^{1}$ Author is researcher at Isparta University of Applied Sciences, Faculty of Technology, Department of Civil Engineering, Isparta, Turkey.
} 


\section{INTRODUCTION}

\section{UVOD}

Cement bonded boards, which are a mixture of wood particles with cement, water and some additives (Marteinsson and Gudmundsson, 2018), have been in use for almost a century. Compared to organic bonded wood products, some advantages such as durability, dimensional stability, acoustic and thermal insulation properties and low production cost make them desirable in the construction industry (Lee, 1984; RamirezCoretti et al., 1998; Savastano et al., 2003; Okino et al., 2005; Del Menezzi et al., 2007). Despite the advantageous properties of $\mathrm{CBP}$, its flexural properties are mostly inferior compared to other wood-based composites. The properties of CBP are significantly influenced by the amount of the cement, woody material and density (Youngquist, 2010). Thus, flexural properties are mostly controlled by the amount of cement. Utilization of alternative woody materials also lower its flexural properties and worsen its dimensional stability.

In order to improve flexural properties of CBP, some pretreatments such as cold or hot water soaking of the particles were found promising (Frybort et al. 2008). During the last few decades, fiberglass has been used with a variety of materials in order to improve strength and stiffness properties (İlhan and Feyzullahoğlu, 2019). Solid wood and wood-based materials are also reinforced with fiberglass and remarkable improvements in bending and other properties were observed (Smulski and Ifju, 1987). Christoforo et al. (2016) obtained doubled bending properties for particleboard by applying fiberglass. Cassidy (2002) observed a $39 \%$ increase in bending strength of oriented strand board (OSB) when reinforced with fiberglass. Fonseca et al. (2011) evaluated the influence of fiberglass reinforcement in plywood panels. Their results showed a $58 \%$ and $43 \%$ increase in bending strength for both longitudinal and transverse directions, respectively. Medium density fiberboard (Cai, 2006) and hardwood panels (Smulski and Ifju, 1987) were also reinforced and significant enhancement was achieved in bending properties.

Reinforcement of CBP with some natural fibers such as bagasse (Aggarwal, 1995) and jute (Deng and Furuno, 2002) were investigated and some improvements in physical and mechanical properties were observed. The literature concerning fiberglass reinforcement of CBP is scarce. A study by Wei and Tomita (2001) investigated the effects of discontinuous glass fiber on cement bonded boards and reported an increasing MOR and internal bond strength but also a decreasing $T S$ and $W A$.

The use of fiberglass reinforcement may help reducing the use of wood material for large and heavy structural wood members as well as minimize mechanical property variability (Rowlands et al. 1986). In this study, FPM was used as reinforcement, and its effects on some physical and mechanical properties of the CBP manufactured were investigated.

\section{MATERIALS AND METHODS}

\section{MATERIJALI I METODE}

Experimental CBPs with the size of $500 \mathrm{~mm} \times$ $500 \mathrm{~mm}$, a thickness of $12 \mathrm{~mm}$ and an average target density of $1300 \mathrm{~kg} / \mathrm{m}^{3}$ were prepared in laboratory conditions. Wood particles were mixed with commercial cement (CEM I 42.5), water and accelerator. Wood/cement ratio was 1:2 and 1:3; water/cement ratio was 1/2.5. Coarse particles of Red pine wood (Pinus brutia), which are used in the core layer of commercial three layer particleboard, were provided from a local particleboard factory. $M C$ of wood particles was $12 \%$. The size distribution of wood particles used in the production of experimental CBP is given in Table 1.

Table 1 Size distribution of wood particles used in the study Tablica 1. Raspodjela drvnog iverja upotrijebljenog $\mathrm{u}$ istraživanju

\begin{tabular}{|c|c|}
\hline Particle size, $\mathrm{mm}$ / Veličina iverja, $\mathrm{mm}$ & $\%$ \\
\hline 6.3 & 0.6 \\
\hline 4 & 4.5 \\
\hline 2 & 29 \\
\hline 1 & 49 \\
\hline 0.85 & 6.6 \\
\hline 0.5 & 8.5 \\
\hline 0.25 & 1.3 \\
\hline 0.125 & 0.5 \\
\hline
\end{tabular}

The amount of $5 \%$ of chemical additives $\left(\mathrm{CaCl}_{2}\right.$, $\mathrm{KCl}$, DARASET ${ }^{\circledR} 580$ ) based on cement mass was added to the water before mixing. $\mathrm{CaCl}_{2}$ is one of the most known accelerators used in wood cement composites. $\mathrm{KCl}$ is usually added to cement mixtures in order to improve the cement/formation bond. DARASET ${ }^{\circledR} 580$ is an admixture for concrete, used to accelerate cement hydration, which causes shortened setting times and increased early compressive strength. FPM (FileTex160 brand) used in the study was woven glass fiber fabric at $4 \mathrm{~mm}$ intervals. Bidirectional FPM weighed $160 \mathrm{~g} / \mathrm{m}^{2}$ and consisted of $80 \%$ fiberglass (Eglass) and $20 \%$ polyester resin binder. In general, FPM is used in exterior plastering, where it helps to prevent stress caused by humidity and extreme temperature changes. It also has the features of anti-corrosion and resistance to alkalis.

Experimental CBP were prepared with and without FPM (Table 2) as follows: first, wood particles were sprayed with water that contains previously dissolved accelerator. Then, cement was added to the mixture until a homogeneous distribution was obtained. The experiment was carried out by spreading the mixture on the steel plate. In the production of experimental CBP with FPM, two plies of FPM were embedded approximately $3 \mathrm{~mm}$ below the board surface. The mixture was placed between steel plates and left for curing under the pressure of $1.8 \mathrm{~N} / \mathrm{mm}^{2}-2.0 \mathrm{~N} / \mathrm{mm}^{2}$. Wax paper was used between cement mixture and steel plates. The cured boards were conditioned in the laboratory climate at approximately $+20{ }^{\circ} \mathrm{C}$ and relative humidity $(\mathrm{RH})$ of $65 \%$. After curing, samples were 
Table 2 Experimental design used in the study

Tablica 2. Dizajn eksperimenta

\begin{tabular}{|c|c|c|}
\hline $\begin{array}{c}\text { Wood - cement ratio } \\
\text { Omjer drvo-cement }\end{array}$ & $\begin{array}{c}\text { Accelerator used } \\
\text { Dodani ubrzivač }\end{array}$ & FPM \\
\hline $33 \%$ wood & $\mathrm{CaCl}_{2}$ & yes \\
\hline & & no \\
\hline & $\mathrm{KCl}$ & yes \\
\hline & & no \\
\hline & Daraset & yes \\
\hline $50 \%$ wood & & no \\
\hline & $\mathrm{CaCl}_{2}$ & yes \\
\hline & & no \\
\hline & $\mathrm{KCl}$ & yes \\
\hline & & no \\
\hline & Daraset & yes \\
\hline & & no \\
\hline
\end{tabular}

prepared in order to determine $W A, T S$ and bending properties.

$W A$ and $T S$ values after 2 and 24 hours of immersion in water were determined according to TS EN 317. MOR and MOE of the boards were determined according to TS EN 310. Five replicates were used for each test and the obtained data were subjected to an analysis of variance. Experimental results were analyzed using ANOVA tests to identify their statistical significance. Duncan's multiple range tests were performed in order to find the least significant difference between all the variables. The obtained results were also compared to standard values of TS EN 634-2.

\section{RESULTS AND DISCUSSION}

\section{REZULTATI I RASPRAVA}

Table 3 and 4 show TS and $W A$ values of the laboratory manufactured CBP samples. Density of the experimental CBP ranges from 1221 to $1345 \mathrm{~kg} / \mathrm{m}^{3}$ and was not significantly different among the tested group. The use of FPM did not significantly alter the density of the CBP manufactured. 2- and 24-hour TS values of the CBP vary between $2.39 \%-12.39 \%$ and $2.6 \%$ $16.57 \%$, respectively.
Overall, $T S$ values of CBP were significantly affected by all the variables involved in the study $(p<$ $\left.0.001, R^{2}=0.83 ; 0.96\right)$. The average 2 -hour - $T S$ values $(3.66 \%)$ of $33 \%$ wood boards were increased to 5.425 $\%$ when the amount of wood particles was increased to $50 \% . \mathrm{CaCl}_{2}$ and $\mathrm{KCl}$ seemed to yield lower 2-hour $T S$ values (3.5\% and $4.09 \%$, respectively) compared to the DARASET $(6.028 \%)$. The use of FPM remarkably dropped the average 2- hour TS values from $5.5 \%$ to $3.5 \%$.

The increase in the amount of wood volume resulted in higher 24-hour TS values as expected (4.69\% to $7.55 \%$ ). Results are compatible with the literature. 24-hour TS values of boards manufactured using $\mathrm{KCl}$ $(4.2 \%)$ were lower than those manufactured using $\mathrm{CaCl}_{2}$ and DARASET (5.8\% and $8.35 \%$ ). The use of FPM remarkably dropped the average 24-hour $T S$ values from $7.8 \%$ to $4.3 \%(80 \%)$.

In general, $W A$ values of CBP were significantly affected by all the variables involved in the study $(p<$ $\left.0.001, R^{2}=0.96 ; 0.97\right) . F$-values indicate that FPM had the greatest influence on $W A$ values than other variables involved. The average 2-hour $W A$ values $(9.33 \%)$ of $33 \%$ wood boards were increased to $12 \%$ when the amount of wood particles was increased to $50 \% . \mathrm{CaCl}_{2}$ seemed to yield lower 2-hour WA values (5.3\%) compared to $\mathrm{KCl}$ and DARASET $(13.1 \%$ and $13.4 \%$, respectively). The use of FPM drastically decreased the average 2-hour $W A$ values from $15.54 \%$ to $5.78 \%$. The average 24-hour $W A$ values $(11.83 \%$ ) of $33 \%$ wood boards were increased to $16.5 \%$ when the amount of wood particles was increased to $50 \% . \mathrm{CaCl}_{2}$ seemed to yield lower 24-hour $W A$ values $(9.5 \%)$ compared to $\mathrm{KCl}$ and DARASET (14.6\% and $18.3 \%$, respectively). The use of FPM drastically decreased the average 24-hour $W A$ values from $20 \%$ to $8.3 \%$.

In general, dimensional stability of the CBP is measured with $T S$ and $W A$, which are dependent on wood particle content (Moslemi and Pfister, 1987; Savastano et al., 2003; Olorunnisola, 2009). Higher wood particle content means lower dimensional stability. In addition to higher particle content, dimensional stability can also be affected by the type of chemical

Table 3 Thickness swelling values after 2 and 24 hours

Tablica 3. Vrijednosti debljinskog bubrenja nakon 2 i 24 sata

\begin{tabular}{|c|c|c|c|c|}
\hline $\begin{array}{c}\text { Wood - cement ratio } \\
\text { Omjer drvo-cement }\end{array}$ & $\begin{array}{c}\text { Accelerator used } \\
\text { Dodani ubrzivač }\end{array}$ & $\begin{array}{c}\text { Plaster net } \\
\text { Fasadna mrežica }\end{array}$ & TS (2 hours), \% & TS (24 hours), \% \\
\hline $33 \%$ wood & $\mathrm{CaCl}_{2}$ & yes & $4.50(0.35)^{*}$ & $5.55(0.43)$ \\
\hline & & no & $2.97(0.46)$ & $4.93(0.46)$ \\
\hline & $\mathrm{KCl}$ & yes & $4.14(2.36)$ & $2.60(0.96)$ \\
\hline & & no & $3.35(0.55)$ & $4.10(1.09)$ \\
\hline & Daraset & yes & $2.39(0.33)$ & $4.50(0.35)$ \\
\hline 50 wood & & no & $4.61(0.29)$ & $6.46(0.35)$ \\
\hline & $\mathrm{CaCl}_{2}$ & yes & $2.74(0.36)$ & $5.04(0.73)$ \\
\hline & $\mathrm{KCl}$ & no & $3.81(0.63)$ & $7.71(0.76)$ \\
\hline & & yes & $3.73(1.26)$ & $5.47(1.02)$ \\
\hline & Daraset & no & $5.94(3.33)$ & $7.39(1.2)$ \\
\hline & & yes & $4.71(1.02)$ & $5.89(1.16)$ \\
\hline
\end{tabular}

*Values in parenthesis are standard deviations. / U zagradama su standardne devijacije. 
Table 4 Water absorption values after 2 and 24 hours

Tablica 4. Vrijednosti upijanja vode nakon 2 i 24 sata

\begin{tabular}{|c|c|c|c|c|}
\hline $\begin{array}{c}\text { Wood - cement ratio } \\
\text { Omjer drvo-cement }\end{array}$ & $\begin{array}{c}\text { Accelerator used } \\
\text { Dodani ubrzivač }\end{array}$ & $\begin{array}{c}\text { Plaster net } \\
\text { Fasadna mrežica }\end{array}$ & WA (2 hours), \% & WA (24 hours), \% \\
\hline $33 \%$ wood & $\mathrm{CaCl}_{2}$ & yes & $6.28(2.17)^{*}$ & $7.85(0.18)$ \\
\hline & & no & $2.81(1.02)$ & $6.47(0.78)$ \\
\hline & $\mathrm{KCl}$ & yes & $5.46(1.27)$ & $7.14(1.34)$ \\
\hline & & no & $17.79(0.91)$ & $17.80(1.03)$ \\
\hline & Daraset & yes & $5.48(1.24)$ & $8.41(0.2)$ \\
\hline 50 wood & & no & $18.15(0.54)$ & $23.33(0.69)$ \\
\hline & $\mathrm{CaCl}_{2}$ & yes & $7.23(1.1)$ & $12.38(4.02)$ \\
\hline & & no & $4.89(1.18)$ & $11.39(1.19)$ \\
\hline & $\mathrm{KCl}$ & yes & $5.92(1.56)$ & $9.65(3.94)$ \\
\hline & Daraset & no & $23.88(4.15)$ & $26.43(1.22)$ \\
\hline & & yes & $4.61(0.12)$ & $6.92(0.18)$ \\
\hline
\end{tabular}

*Values in parenthesis are standard deviations. / U zagradama su standardne devijacije.

accelerators, which are highly hygroscopic, and type of wood particles (Olorunnisola, 2009) and (Moslemi and Pfister, 1987). It seems that $T S$ values of all experimental boards were higher than $1.5 \%$ as required by the standard, while most of the $W A$ values were less than $32 \%$ (TS EN 634-2). Application of pre-treatment or using smaller particles in the board production may help lowering TS and WA values (Moslemi et al., 1983; Lee, 1984; Zhengtian and Moslemi, 1985; Badejo, 1988; Lee and Short, 1989). Compared to $10.4 \%$ $19.2 \%$ decrease in TS values obtained by the use of discontinuous glass fiber (Wei and Tomita, 2001), FPM causes a significant decrease of $80 \%$ in TS. Compared to $14.1 \%-19.9 \%$ decrease in $W A$ values obtained by the use of discontinuous glass fiber (Wei and Tomita, 2001), FPM resulted in a remarkable decrease of 140 $\%$ in $W A$. It seems that embedded FPM, $3 \mathrm{~mm}$ below the surface, plays an important role in control of dimensional stability. Improved dimensional stability may be attributed to higher surface area of bonding between FPM and cement thus blocking the penetration of water molecules through to wood particles of the CBP (Wei and Tomita, 2001).
The bending properties of CBP manufactured in the study are presented in Table 5. MOR and MOE of the experimental CBP were significantly affected by the variables involved in the study $\left(\mathrm{p}<0.001, \mathrm{R}^{2}=\right.$ $0.94,0.98)$. FPM seemed to have a serious effect on bending properties of CBP manufactured. Lowering the amount of wood in the mixture increases the $M O E$ and MOR of the boards from $2485 \mathrm{~N} / \mathrm{mm}^{2}$ to $3241 \mathrm{~N} /$ $\mathrm{mm}^{2}$ and $10.2 \mathrm{~N} / \mathrm{mm}^{2}$ to $11.9 \mathrm{~N} / \mathrm{mm}^{2}$, respectively. Since stiffness of the CBP is dependent on the amount of cement, which is more rigid than wood, it is expected to achieve higher $M O E$ values with lower wood particle content (Moslemi and Pfister, 1987). The use of FPM resulted in an overall increase of $105 \%$ in bending MOE (1876 N/mm² to 3850$)$ of the manufactured boards. The use of different chemical accelerators also showed significantly different results in $M O E$ values of $\mathrm{CBP}$ manufactured. The use of $\mathrm{CaCl}_{2}$ yielded higher average $M O E$ values than other chemicals used.

In general, lowering cement-wood ratio results higher MOR (Moslemi and Pfister, 1987; Papadopoulos et al., 2006), which is contrary to the findings of the present study. This may be a result of interactions of

Table 5 Bending properties of boards

Tablica 5. Savojna svojstva ploča

\begin{tabular}{|c|c|c|c|c|}
\hline $\begin{array}{l}\text { Wood - cement ratio } \\
\text { Omjer drvo - cement }\end{array}$ & $\begin{array}{c}\text { Accelerator used } \\
\text { Dodani ubrzivač }\end{array}$ & $\begin{array}{c}\text { Plaster net } \\
\text { Fasadna mrežica }\end{array}$ & $M O R, \mathbf{N} / \mathbf{m m}^{2}$ & $M O E, \mathrm{~N} / \mathrm{mm}^{2}$ \\
\hline \multirow[t]{6}{*}{$33 \%$ wood } & $\mathrm{CaCl}_{2}$ & yes & $15.45(0.35)^{*}$ & $3903(276)$ \\
\hline & & no & $10.95(0.12)$ & $3353(276)$ \\
\hline & $\mathrm{KCl}$ & yes & $17.11(0.33)$ & $4235(234)$ \\
\hline & & no & $5.95(0.66)$ & $1354(26)$ \\
\hline & Daraset & yes & $11.52(0.17)$ & 4457 (637) \\
\hline & & no & $10.71(0.72)$ & $2145(119)$ \\
\hline \multirow[t]{6}{*}{$50 \%$ wood } & $\mathrm{CaCl}_{2}$ & yes & $15.54(0.74)$ & $3322(112)$ \\
\hline & & no & $9.86(0.33)$ & $3073(907)$ \\
\hline & $\mathrm{KCl}$ & yes & $11.88(0.121)$ & $3660(881)$ \\
\hline & & no & $7.05(0.65)$ & $633(30)$ \\
\hline & Daraset & yes & $13.15(0.15)$ & $4247(253)$ \\
\hline & & no & $3.72(0.33)$ & $702(24)$ \\
\hline
\end{tabular}

*Values in parenthesis are standard deviations. / U zagradama su standardne devijacije. 
the variables used in the study. The use of FPM created an overall increase of $75 \%$ in bending MOR $(8.04 \mathrm{~N} /$ $\mathrm{mm}^{2}$ to $14.1 \mathrm{~N} / \mathrm{mm}^{2}$ ). The use of different chemical accelerators also resulted in significantly deviating results in $M O R$ values of CBP manufactured. The use of $\mathrm{CaCl}_{2}$ yielded higher average $M O R\left(12.95 \mathrm{~N} / \mathrm{mm}^{2}\right)$ values than other chemicals used.

Compared to $15.6 \%-23.2 \%$ MOR increase obtained by the use of discontinuous glass fiber (Wei and Tomita, 2001) and $52 \%$ increase of bagasse (Aggarwal, 1995), FPM provides superior bending resistance.

The average MOR values of the experimental CBP with FPM satisfy the minimum standard value of $9 \mathrm{~N} / \mathrm{mm}^{2}$ required by the standard (TS EN 634-2). $M O R$ values of CBP without FPM are mostly inferior. $M O R$ values are satisfied when $\mathrm{CaCl}_{2}$ is used as accelerator. No experimental CBP resulted in an acceptable $M O E$ value required by the standards (TS EN 634-2), although $M O E$ values were increased with the use of FPM. Higher MOE may be achieved with lower particle content for cement bonded boards (Al Rim et al., 1999) or with higher density (Moslemi and Pfister, 1987; Oyagade, 1990). According to Bejo et al. (2005), mechanical properties of CBP may be increased when densification is increased. Since fiberglass in general has superior tensile strength and stiffness, two plies of FPM make great contribution to the bending properties of CBP.

The main reason behind the inadequate physical and mechanical properties of the boards manufactured in the study could be the use of only coarse wood particles. Coarse particles could not be easily compressed as fine particles, which resulted in some gaps or voids during manufacturing, thus yielding undesirable board properties. Bending properties of the CBP may also be improved by the application of pretreatments, which were found acceptable for many lingo-cellulosic materials (Moslemi et al., 1983; Lee, 1984; Zhengtian and Moslemi, 1985; Lee and Short, 1989).

\section{CONCLUSIONS}

\section{ZAKLJUČAK}

The effects of FPM as reinforcement on selected mechanical and physical properties of CBP were studied. The results indicated that embedment of two plies of FPM near the surface of CBP improves $M O E$ and $M O R$ as well as resistance to TS and $W A$. An application of two plies of FPM increased MOE and MOR of CBP by $75 \%$ and $105 \%$, respectively, reduced $W A$ up to $140 \%$ percent, and reduced TS up to $80 \%$. FPM could be used for improvement of CBP properties, as an alternative to other pretreatments, chemical additives or reinforcing materials. Besides improving inadequate board properties, the application of FPM may help lowering the weight of the CBP, which is a disadvantage compared to similar wood base composites. Furthermore, utilization of agricultural residues, which usually result in inferior board properties in the manufacture of CBP, may be facilitated.

\section{REFERENCES}

\section{LITERATURA}

1. Aggarwal, L. K., 1995: Bagasse-reinforced cement composites. Cement and Concrete Composites, 17 (2): 107112. https://doi.org/10.1016/0958-9465(95)00008-Z.

2. Al Rim, K.; Ledhem, A.; Douzane, O.; Dheilly, R. M.; Queneudec, M., 1999: Influence of the proportion of wood on the thermal and mechanical performance of clay-cement-wood composites. Cement Concrete Composites, 21: 269-276. http://dx.doi.org/10.1016/S0958-9465(99)00008-6.

3. Badejo, S. O. O., 1988: Effect of flake geometry on properties of cement-bonded particleboard from mixed tropical hardwoods. Wood Science and Technology, 22 (4): 357-369. https://doi.org/10.1007/BF00353325.

4. Bejo, L.; Takats, P.; Vass, N., 2005: Development of cement bonded composite beams. Acta Silva Lignaria Hungary, 1: 111-119.

5. Cai, Z., 2006: Selected properties of MDF and flake board overlaid with fiberglass mats. Forest Products Journal, 56 (11/12): 142-146.

6. Cassidy, E. D., 2002: Development and structural testing of FRP reinforced OSB panels for disaster resistant construction. Dissertation in Master of Science, The University of Maine, Maine, 2002.

7. Christoforo, A. L.; Do Nascimento, M. F.; Panzera, T. H.; Filho, S. L. M. R.; Lahr, F. A. R., 2016: Homogeneous Pinus spp. particle boards reinforced with laminated composite materials. Journal of the Brazilian Association of Agricultural Engineering, 36 (3): 558-565.

8. Del Menezzi, C. H. S.; De Castro, G. H.; De Souza, M. R., 2007: Production and properties of a medium density wood-cement boards produced with oriented strands and silica fume. Maderas. Ciencia y tecnología, 9 (2): 105115.

http://dx.doi.org/10.4067/S0718-221X2007000200001.

9. Deng, Y. H.; Furuno, T., 2002: Study on gypsum-bonded particleboard reinforced with jute fibres._Holzforschung, 56 (4): 440-445. http://dx.doi.org/10.1515/HF.2002.068.

10. Fonseca, C. B.; Costa, G. F.; Dias, F. M., 2011: Reforço com fibras de vidro em painéis compensados uma alternativa ecológica. VIII SEGeT- Simposio de Excelencia em Gestao e Tecnologia.

11. Frybort, S.; Mauritz, R.; Teischinger, A.; Müller, U., 2008: Cement bonded composites: a mechanical review. BioResources. 3 (2): 602- 626.

12. İlhan, R.; Feyzullahoğlu, R., 2019: Natural fibers and filler materials used in glass fiber reinforced polyester (GFRP) composite materials. El-Cezerî Journal of Science and Engineering, 6 (2): 355-381. http://dx.doi.org/10.31202/ecjse.519072.

13. Lee, A. W. C., 1984: Physical and mechanical properties of cement bonded southern pine excelsior. Forest Products Journal, 34 (4): 30-34.

14. Lee, A. W. C.; Short, P. H., 1989: Pre-treating hardwood for cement-bonded excelsior board. Forest Products Journal, 39 (10): 68-70.

15. Marteinsson, B.; Gudmundsson, E., 2018: Cement bonded particle boards with different types of natural fibers using carbon dioxide injection for increased initial bonding. Open Journal of Composite Materials, 8 (1): 28-42. http://dx.doi.org/10.4236/ojcm.2018.81003.

16. Moslemi, A. A.; Garcia, J. F.; Hofstrand, A. D., 1983: Effect of various treatments and additives on wood-Portland cement-water systems. Wood and Fiber Science, 15 (2): 164-176. 
17. Moslemi, A. A.; Pfister, S. C., 1987: The influence of cement wood ratio and cement type on bending strength and dimensional stability of wood cement composite panels. Wood Fiber Science, 19: 165-175.

18. Okino, E. Y. A.; Souza, M. R.; Santana, M. A. E.; Alves, M. V. S.; Sousa, M. E.; Teixeira, D. E., 2005: Physicomechanical properties and decay resistance of Cupressus spp. cement-bonded particleboards. Cement and Concrete Composites, 27 (2): 333-338. https://doi.org/10.1016/j.cemconcomp.2004.02.046.

19. Olorunnisola, A. O., 2009: Effects of husk particle size and calcium chloride on strength and sorption properties of coconut husk-cement composites. Industrial Crops and Products, 29 (2/3): 495-501. https://doi.org/10.1016/j.indcrop.2008.09.009.

20. Oyagade, A. O., 1990: Effect of cement/wood ratio on the relationship between cement bonded particleboard density and bending properties. Journal of Tropical Forest Science, 2 (2): 211-219.

21. Papadopoulos, A. N.; Ntalos, G. A.; Kakaras, I., 2006: Mechanical and physical properties of cement bonded OSB. Holz als Roh- und Werkstuff, 64: 517-518. https://doi.org/10.1007/s00107-005-0092-6.

22. Ramirez-Coretti, A.; Eckelman, C. A.; Wolfe, R. W., 1998: Inorganic-bonded composite wood panel systems for low-cost housing: a Central American perspective. Forest Products Journal, 48: 62-68.

23. Rowlands, R. E.; Van Deweghe, R. P.; Laufenberg, T. L.; Krueger, G. P., 1986: Fiber-reinforced wood composites. Wood and Fiber Science, 18 (1): 39-57.

24. Savastano, H.; Warden, P. G.; Coutts, R. S. P., 2003: Potential of alternative fiber cements as building materials for developing areas. Cement and Concrete Composites, 25: 585-592. https://doi.org/10.1016/S0958-9465(02)00071-9.

25. Smulski, S. J.; Ifju, G., 1987: Flexural behavior of glass fiber reinforced hardboard. Wood and Fiber Science, 19 (3): 313-327.
26. Youngquist, J. A., 2010: Wood-based composites and panel products. In: Wood Handbook: Wood as an Engineering Material (ed. Ross, R. J.). General Technical Report FPL-GTR 190, U.S. Department of Agriculture, Forest Service, Forest Products Laboratory, Madison, WI.

27. Wei, Y. M.; Tomita, B., 2001: Effects of five additive materials on mechanical and dimensional properties of wood cement-bonded boards. Journal of Wood Science, 47: 437-444.

28. Zhengtian, L.; Moslemi, A. A., 1985: Influence of chemical additives on the hydration characteristics of western larch wood-cement- water mixtures. Forest Products Journal, 35 (7): 37-43.

29. ***TSE, 1999: Wood- Based panels- Determination of modulus of elasticity in bending and of bending strength. TS EN 310, Ankara.

30. ***TSE, 1999: Particleboards and fiber boards- Determination of swelling in thickness after immersion in water. TS EN 317, Ankara.

31. ***TSE, 2009: Cement-bonded particleboards- Specifications- Part 2: Requirements for Portland cement bonded particleboards for use in dry, humid and exterior conditions. TS EN 634-2, Ankara.

\section{Corresponding address:}

\section{HASAN HÜSEYIN TAŞ}

Isparta University of Applied Sciences

Faculty of Technology

Department of Civil Engineering

32260, Isparta, TURKEY

e-mail: huseyintas@isparta.edu.tr 